\title{
Assessing design information quality in the construction industry: Evidence from building information modeling
}

\author{
Jahanzeb ASIM ${ }^{1}$, Rizwan Raheem AHMED ${ }^{2}$, Dalia STREIMIKIENE ${ }^{3 *}$, \\ Sarah RASHEED ${ }^{4}$ and Justas STREIMIKIS ${ }^{5,6}$
}

Authors' affiliations and addresses:

${ }^{1}$ Faculty of Management Sciences, Shaheed

Zulfikar Ali Bhutto Institute of Science \&

Technology, 100 Clifton, Block-5, Karachi -

75600, Sindh, Pakistan

e-mail: jahanzeb.asim@szabist.pk

${ }^{2}$ Faculty of Management Sciences, Indus University, Gulshan-17, Karachi-75300, Pakistan e-mail: rizwanraheemahmed@gmail.com

${ }^{3}$ Institute of Sport Science and Innovations, Lithuanian Sports University, Sporto str. 6, Kaunas, Lithuania

e-mail: dalia.streimikiene@lei.lt

${ }^{4}$ Faculty of Management Sciences, Shaheed Zulfikar Ali Bhutto Institute of Science \& Technology, 100 Clifton, Block-5, Karachi 75600, Sindh, Pakistan

e-mail: engg.rasheedsarah@gmail.com

${ }^{5}$ Institute of Economics and Rural Development, Lithuanian Centre for Social Sciences, A.

Vivulskio g. 4A-13, LT-03220 Vilnius, Lithuania e-mail: justas.streimikis@gmail.com

${ }^{6}$ Faculty of Management and Finances,

University of Economics and Human Science in Warsaw, Okopowa 59, 01-043 Warsaw, Poland e-mail: justas.streimikis@gmail.com

\section{*Correspondence:}

Dalia Streimikiene, Institute of Sport Science and Innovations, Lithuanian Sports University, Sporto str. 6, Kaunas, Lithuania

e-mail: dalia.streimikiene@lei.lt

How to cite this article:

Asim, J., Ahmed, R. R., Streimikiene, D. Rasheed, S. and Streimikis, J. (2021). Assessing design information quality in the construction industry: Evidence from building information modeling. Acta Montanistica Slovaca. Volume 26 (2) $235-251$

DOI:

https://doi.org/10.46544/AMS.v26i2.05

\begin{abstract}
The objective of the undertaken study is to assess the application of Building Information Modeling (BIM) and evaluate the quality of information on construction projects. The paper also focuses on examining the design information quality on construction projects by applying BIM based on perceived variables, for instance, improve workflow, improve collaboration, design visualization, lower cost, environmental impact analysis, and variations. The first objective was to evaluate the impact of building information modeling on perceived variables such as improve workflow, improve collaboration, design visualization, lower cost, environmental impact analysis, and variations. We also evaluated the impact of these six constitutes of BIM, for instance, improve workflow, improve collaboration, design visualization, lower cost, environmental impact analysis, and variations on reducing design information problem. Finally, we have evaluated the mediating impact of improve workflow, improve collaboration, design visualization, lower cost, environmental impact analysis, and variations between building information modeling and reducing design information problems. In the last, we also examined the impact of BIM on reducing design information problems. In this context, the closed-ended five-point Likert scale adapted questionnaire was distributed among construction professionals, and data were analyzed through structural equation modeling and multivariate techniques using statistical software. The findings demonstrated that BIM has a significant \& positive impact on its six constitutes. Additionally, we examined these constitutes such as improve workflow, improve collaboration, design visualization, lower cost, environmental impact analysis, and variations have a significant impact on reducing design information problems. The results also significantly contributed to the fact that BIM has a significant impact on reducing design information problems, ultimately playing a pivotal role in assessing design information quality on projects.
\end{abstract}

\section{Keywords}

Improve workflow, improve collaboration, design visualization, lower cost, energy efficiency, design information quality, structural equation modeling, multivariate techniques. 


\section{Introduction}

The construction industry is striving towards high expectations, regardless of the design outlook. Still, the design quality as well that assures high-quality information is readily available with the execution team throughout the project life cycle (Guo \& Ma, 2021; Aladag et al., 2016). Regrettably, it is a fact that either there is too much information that needs to be handled carefully or not good enough to achieve high-quality performance through the project. The deficiency is not only on the part of designers; instead, every stakeholder's contribution is required. The execution team's information regarding site conditions, procedures, and schedule is equally crucial for selecting the right design. Dahmani et al. (2021) and Sutrisna and Goulding (2019) briefly describe design information as a complete package not only comprising drawings, specifications, and 3D models but also sufficient information, correspondence, meeting minutes, answers to queries, and changes that should be well-coordinated between the design and execution team to plan and execute construction work (Al Mousli \& El-Sayegh, 2016).

A higher number of uncertainties describe the building design due to undefined requirements, solutions, and output. The level of intricacy increases due to the interdependency of design information and multifaceted activities, making the design further complex. To evaluate the success criteria of a project, time, cost, and quality are the three main components that need to be assessed before the commencement of a project (Chen et al., 2020a; Frefer et al., 2018). The end-user requirements and quality standards are predefined at the design stage through detailed drawings, technical specifications, and work procedures. Therefore, design management should be targeted towards organized processes and a professional design team to navigate a project (Andújar-Montoya et al., 2019; Al Hattab \& Hamzeh, 2016).

Many researchers have hypothesized that the construction project designs can be significantly improved by applying advanced construction practices and adopting the increasing use of Building Information Modeling (BIM) (Chu et al., 2019; Tauriainen et al., 2016). Thus, in recent years, BIM has been broadly discussed both within the literature and in the construction sector. The development momentum of BIM has been continuously increasing and is considered a critical enabler to embed digital processes within organizations. Further to this, BIM is also considered design automation in the construction industry after using the CAD system. Martinez et al. (2021) and Heaton et al. (2019) explained that BIM has been widely adopted by the lead designers, constructors, and supply team during design and construction phases, and demonstrated a noticeable decrease in cost, increase productivity, and improved risk management processes (Dai et al., 2018). BIM acts as a basis for a parametric study that stores the building data on a 3D database and supports 3D visualization and infrastructure construction efficiently. Ogwueleka and Ikediashi (2017) emphasized that BIM improves overall project efficiency and achieves quality standards by preserving graphic designs and accumulating detailed information on materials used, technical specifications, forms, etc.

The idea of BIM is to support project information exchange - thus acts as an information management system. The quality of the information in construction projects is often inferior and challenging to locate various implicit, missing, outdated, or even scattered pieces in several different documents (Yousefikhah et al., 2017; Mahmudin et al., 2020). The deficiencies are not only on the part of designers; instead, the design process involves various participants' interference. The information from different participants regarding constructability, schedule, and economy is essential for selecting the right design. It has to be well integrated other than the overall design to reduce the level of complexity (Baskakov, 2019). The construction industry has to take immediate measures. It has mitigated the consequences of design complexity on construction projects' quality and schedules.

In the light of the above context, there appears to be a dire need to incorporate technological evolutions into practice to evaluate the design information quality that will provide major benefits to the construction industry (Bell et al., 2018). The design information problems from contractors' perspective during construction and approach towards monitory benefit have a significant impelled to integrate BIM into its operation (Bekdik et al., 2018). To achieve quality conformance, information requirements must be task-specific and well-defined. This research helps in evaluating the quality of design information, ultimately leading towards economic stability. Also, this study provides a foundation basis for academia and practice that monitors the effect of potential developments.

The rest of the research study comprises the following: section 2 contains the literature review and established the research hypotheses, the methodology of the undertaken study presented in section 3, which followed by section 4 in which results and findings of the study are presented. However, section 5 comprised of discussions, and section 5 exhibited the conclusions of the study and future directions of research works.

\section{Literature review and hypotheses development}

The capacity to utilize BIM essentially to develop a building earlier than the development of real building gives enviable implies to check its constructability with the real world and resolve any instabilities amid the 
procedure. This permits for more proficient, better-designated structures that constrain an asset's squander, optimize vitality utilization, and advance inactive plan methodologies (Yap \& Skitmore, 2018; Al Hattab \& Hamzeh, 2016). BIM is the most recent era of object-oriented CAD frameworks in which all of the smart building objects combine to form up a building plan. BIM, in theory, gives a single, coherent, reliable resource for all data related to the building (Guo \& Ma, 2021).

Design management. To go all-out and be competitive, the construction industry should strive for innovative ideas, methodology, and techniques for delivering a product (Olawumi \& Chan, 2018). Design management is about managing all the stakeholders on a project, involving innovative design and concepts, specification, serviceability, and limitations. Yassin et al. (2020), von Heyl and Dem (2019), and Mollasalehi et al. (2017) identified major design information management problems that affect the overall project progress, such as lack of communication, insufficient documentation, unbalanced sharing of resources, unreliable decision-making, frequent changes, and poor or missing input (Burggräf et al., 2019).

Design information problems. Since building construction, the design phase is considered an iterative process, where frequent design changes and deviations are inevitable. Mahmudin et al. (2020) conducted a survey and disclosed the most significant design phase problems: lack of internal coordination, insufficient contract document, lack of specialist contract managers, and lack of project management expertise. Vardanyan (2019) and Sha'ar et al. (2017) discussed design construction interface problems concerning client-related (scope changes, knowledge to comprehend and visualize the project, delay in decision making, etc.), consultant related (unstructured design process, poor coordination, and communication between designers and client/contractor parties, ineffective utilization of automation, no system of design checking, lack of adequate design changes, lack of design standards, etc.) (Chen et al., 2020a). Contractor-related (insufficient working drawings, shop drawings submission and approval, incomplete specifications, lack of expertise, etc.). Similarly, Villena et al. (2020) and Lin and Jeng (2017) emphasized over 20 owner-designers interface problems, categorized into three groups: inadequate contractual stipulations, financial issues, and lack of communication.

BIM implementation in the AEC industry. In recent years, a lot of research has been conducted on implementing BIM in the Architectural, Engineering, and Construction (AEC) industry. Chen et al. (2020b) and Bradley et al. (2016) explained the benefits of BIM implementation on infrastructure projects through case study findings; that reveal a considerable decrease in change orders and requests for information (RFIs) and conformance towards project timelines. BIM supports construction actions by encouraging collaboration between all stakeholders (Sampaio, 2017). Oldfield et al. (2017) explained that BIM, when combined with other contracts, upholds information integrity and transparency across the project lifecycle and enables the built assets to be more productive, predictable, and profitable. It is evident from the literature that BIM contributes towards project success in terms of improved design quality, information storing and sharing ability, reduced constructs cost and errors, lowering work duration, enhancing work efficiency, and supporting management decisions (Troiani et al., 2020; Doumbouya et al., 2016). This research's main focus is to study the impact of BIM in reducing design information problems (Dai et al., 2018). So, BIM acts as an independent variable (IV) and design information problems as a dependent variable (DV). The independent variable (BIM) is further branched into six variables (IVs) (workflow, collaboration, design visualization, cost, environmental impact analysis, and variations (Donato et al., 2018). Thus, we have first checked the relationship between BIM and its constituents, for instance, improving workflow, improving collaboration, design visualization, lower cost, environmental impact analysis, and reducing variations. Additionally, BIM has a significant impact in reducing design information problems (Dahmani et al., 2021). It is logically assumed in the form of the following hypotheses:

H1: $\quad$ BIM has a significant \& positive association with improves workflow.

H2: $\quad$ BIM has a significant \& positive association with improves collaboration.

H3: $\quad$ BIM has a significant \& positive association with design visualization.

H4: $\quad$ BIM has a significant \& positive association with lower cost.

H5: $\quad$ BIM has a significant \& positive association with environmental impact analysis.

H6: $\quad$ BIM has a significant \& positive association with reduces variations.

H7: $\quad$ BIM has a significant impact in reducing design information problems.

Improves workflow. BIM facilitates collaboration among different disciplines, enabling an integrated design, a virtual database containing everything needed to assess the sustainability level (Bergonzoni et al., 2021; Son et al., 2017). BIM-integrated workflows support complex sustainable decision-making in the future (Feng \& Chen, 2019). Chen et al. (2020a), and Rezaei et al. (2019), explained BIM and Radio Frequency Identification (RFID) technologies improve supply chain visibility and coordination of material flow processes. Thus, based on previous literature, we framed the following hypothesis:

H8: $\quad$ Improve workforce has a significant impact in reducing design information problems.

Improves collaboration. From a technical perspective, progressive use of BIM and integrated tools reduces manual information requirement, decreases process time, and lowers the chance of miscommunication, resulting in reduced execution time and reduced development cost (Chen et al., 2020b). Further assists in administrative 
procedures and information flow. This was originated by building SMART (Son et al., 2019; Gbadamosi et al., 2019). Literature reveals that building SMART's IDM methodology provides comprehensive information exchange specifications that function as a basis for process automation and software application, resulting in reduced manual data in the sustainable design process (Petrova et al., 2017; Pełczyński et al., 2021). Thus, based on previous literature, we framed the following hypothesis:

H9: Improve collaboration has a significant impact in reducing design information problems.

Design visualization. BIM is considered as a multidimensional 3D representation of the physical and functional characteristics of a building. It generates graphical imaginaries that make the concepts and options clearer (Ren et al., 2019; Gogtay \& Thatte, 2017). 3D Visualizations, project participants can portray the entire outlook of the building design before it is executed (Suryanto et al., 2016; Röck et al., 2018a). It generates building mockups that enable architects to collaborate with the contractors and suppliers, ultimately reducing project uncertainties (Frefer et al., 2018; Chen et al., 2020b). Thus, based on previous literature, we framed the following hypothesis:

H10: Design visualization has a significant impact in reducing design information problems.

Lowers cost. Guo et al. (2021) and Sakin and Kiroglu (2017) explained that integrating BIM methodology with 3D printing modeling helps in better design, cost reduction, energy efficiency, and isolation of structure. Several research studies have demonstrated that a lower cost visualization significantly reduces design information problems (Sutrisna et al., 2018; Petrova et al., 2017; Bergonzoni et al., 2021; Chen et al., 2020a). Thus, based on previous literature, we framed the following hypothesis:

H11: Lowering cost has a significant impact in reducing design information problems.

Environmental impact analysis. Energy efficiency is considered to be a useful element while considering building materials to be environmentally friendly. The main objective of using energy-efficient materials is to reduce toxins and artificially generated power at the building site (Juszczyk et al., 2016; Arshad et al., 2017). BIM helps users with an opportunity to explore different energy-saving options at early stages and to evaluate a variety of material compositions to the embodied impact of the building design (Röck et al., 2018b). Further, it helps to identify design-related hotspots and potentials for reducing the embodied impact of a building (Guo et al., 2019). Thus, based on previous literature, we framed the following hypothesis:

H12: Environmental impact analysis has a significant impact in reducing design information problems.

Reduces variations. BIM is considered an effective solution to myriad issues, a poor workflow that plagues the design process, resulting in reworks, errors, variations, and cost overruns that are detrimental to the projects (Khilnani, 2018; Al Hattab \& Hamzeh, 2016). Several research studies have demonstrated that reduces variation has a significant impact in reducing design information problems, for instance, Mollasalehi et al. (2017) and Lin and Jeng (2017). Thus, based on previous literature, we framed the following hypothesis:

H13: Reduces variation has a significant impact in reducing design information problems.

The indirect effect of factors. We have developed a modified model for BIM. We also used the individual constituents of BIM to improve workflow, improve collaboration, design visualization, lower cost, environmental impact analysis, and reduce variations. From Figure 1, it is evident that BIM has a direct association with individual factors such as improving workflow, improving collaboration, design visualization, lower cost, environmental impact analysis, and reducing variations (Konigsberg \& Frankenberg, 2018; Al Mousli \& El-Sayegh, 2016; Mollasalehi et al., 2017). Additionally, BIM has a significant impact in reducing design information problems. Figure 1 also demonstrated an indirect association between BIM and reducing design information problems with the help of BIM elements (improve workflow, improve collaboration, design visualization, lower cost, environmental impact analysis, and reduce variations). Thus, according to previous literature, we also established the mediation of improving workflow, improve collaboration, design visualization, lower cost, environmental impact analysis, and reduces variations between BIM and reducing design information problems, for instance, Al Hattab and Hamzeh (2015), Arshad et al. (2017), Röck et al. (2018b), Sakin and Kiroglu (2017), Petrova et al. (2017), Bergonzoni et al. (2021), and Chen et al. (2020b). Thus, we framed the following hypotheses:

H14A: Improve workflow has a significant mediating effect between BIM and reducing design information problems.

H14B: Improve collaboration has a significant mediating effect between BIM and reducing design information problems.

H14C: Design visualization has a significant mediating effect between BIM and reducing design information problems.

H14D: Lower cost has a significant mediating effect between BIM and reducing design information problems.

H14E: Environmental impact analysis has a significant mediating effect between BIM and reducing design information problems.

H14F: Reduces variations have a significant mediating effect between BIM and reducing design information problems. 


\section{Materials and Methods}

Research objective of the study. The objective of the undertaken study is to assess the application of BIM and evaluate the quality of information on construction projects. The paper also focuses on examining the design information quality on construction projects by applying BIM based on perceived variables, for instance, improve workflow, improve collaboration, design visualization, lower cost, environmental impact analysis, and variations. The first objective was to evaluate the impact of building information modeling on perceived variables such as improve workflow, improve collaboration, design visualization, lower cost, environmental impact analysis, and variations. The second objective of this research was to examine the impact of these six constitutes of BIM, for instance, improve workflow, improve collaboration, design visualization, lower cost, environmental impact analysis, and variations on reducing design information problem. Finally, we have evaluated the mediating impact of improve workflow, improve collaboration, design visualization, lower cost, environmental impact analysis, and variations between building information modeling and reducing design information problems. In the last, we also examined the impact of BIM on reducing design information problems.

Research design and scaling. The research is quantitative in nature and is based on the descriptive \& crosssectional design. It makes statistical inferences about a population of interest within a single frame of time. A deductive approach has been used for this research to explore a known theory and confirm its validity based on given circumstances. It has been observed that the deductive approach starts with a theory that generates a new hypothesis which is then tested by challenging it with the observations that may either lead to confirmation or rejection of the hypothesis (Mahmudin et al., 2020). A mono-method research choice is required since our focus has been entirely on a quantitative data collection method through the survey. The scales of the constructs have been extracted as follows: the scales of reducing design information problems were taken from previous literature, such as Mahmudin et al. (2020), Vardanyan (2019), Sha'ar et al. (2017), Chen et al. (2020a), Villena et al. (2020), and Lin and Jeng (2017). The scales of building information modeling were obtained and modified from previous studies, for instance (Chen et al., 2020b; Bradley et al., 2016; Sampaio, 2017; Oldfield et al., 2017; Troiani et al., 2020; Doumbouya et al., 2016; Dai et al., 2018; Dahmani et al., 2021). Similarly, items (scales) of improve workflow were extracted from previous literature such as (Bergonzoni et al., 2021; Son et al., 2017; Feng \& Chen, 2019; Rezaei et al., 2019), scales of improve collaboration were taken \& modified from previous studies (Son et al., 2019; Gbadamosi et al., 2019; Petrova et al., 2017; Pełczyński et al., 2021). The modified items (scales) of design visualization were taken from previous literature such as (Ren et al., 2019; Gogtay \& Thatte, 2017; Suryanto et al., 2016; Röck et al., 2018a; Frefer et al., 2018), modified scales of lowers cost were extracted from previous studies such as Guo et al., 2021; Sakin \& Kiroglu, 2017; Sutrisna et al., 2018; Bergonzoni et al., 2021). However, the modified items (scales) of environmental impact analysis were taken from previous literature such as (Juszczyk et al., 2016; Arshad et al., 2017; Röck et al., 2018b; Guo et al., 2019). Finally, the modified items of reducing variations were extracted from the previous studies, for instance, Khilnani (2018), Al Hattab and Hamzeh (2016), Mollasalehi et al. (2017), and Lin and Jeng (2017).

Data collection and sampling strategy. An online and offline questionnaire survey form was administered among study participants through personal emails obtained from LinkedIn and companies' websites. Additionally, data was obtained from social media groups, for instance, Facebook and WhatsApp groups. The nature of questions is comprised of two parts. Annexure 1 contains demographic questions, and Annexure 2 consisted of main hypotheses questions. The authors' have employed a 5-point Likert scale from strongly disagree (1) to strongly agree (5) Likert-scale system for assessment. The sampling frame considered for this study is professionals from the construction industry in Pakistan, including architects, consultants, contractors, engineers, and other domain particulars with relevant practical work experience. The data was collected from September 2019 to April 2020, and after that, COVID-19 has restricted everything. Thus, we had to stop collecting the data. We obtained filled questionnaires through personal emails, social media groups, and inperson. Since we had to receive the responses from our target group thus, we employed the purposive sampling technique. A total of six hundred (600) questionnaires were distributed, and we received 523 responses completely and properly filled in which 259 responses were obtained through in-person administration of the questionnaire. The rest of 341 responses were obtained online. Hence, the response rate was $87.17 \%$.

Data estimations techniques. This research's main objective was to find out the significance of BIM in assessing design information quality in the Pakistan construction industry. This section has been premeditated to critically analyze the primary data extracted from the questionnaire (based on 5-point Likert-Scale), which is then run on Smart-PLS 3.1.6 software to determine the relationship between the dependent and independent variables (Ringle et al., 2015). Since this research is based on the mono method quantitative approach, descriptive statistics and structural equation modeling are used. The data was evaluated in two steps; in the first phase, we examined the measurement model through Cronbach's alpha (CA), composite reliability (CR), and average variance extracted (AVE) (Taber, 2018). We measured convergent and discriminant validities of items and constructs. For this purpose, we further used HTMT and Fornell and Larcker (1981) techniques. Finally, we 
evaluated the structural model through R-square values, path co-efficient analysis, SRMR indicators, and StoneGeisser $\left(Q^{2}\right)$ values (Ahmed et al., 2019). Finally, the outcomes were validated through Eigenvalues and Multivariate Tests.

Respondents' demography. The respondents' demographic profiles suggested that $42.5 \%$ have less than 5 years of experience, $33.33 \%$ engineers, $25.49 \%$ architects, $13.7 \%$ consultants, and $9.80 \%$ contractors, while the rest are in the other category. Around $33.33 \%$ hold 6 to 10 years of experience, consisting of $42.5 \%$ engineers, $20 \%$ consultants, $17.5 \%$ architects, $15 \%$ contractors, and the remaining rest in other categories. Similarly, $15 \%$ have 11 to 15 years of experience, $38.8 \%$ are engineers, $22.2 \%$ are consultants and contractors, $11.1 \%$ are architects, and while the rest are in others categories. Likewise, $7.5 \%$ have around 16 to 20 years of experience, while only $1.67 \%$ have more than 20 years of experience. The majority of the construction professionals $(37.5 \%)$ use AutoCAD MEP software in their organizations. Around 19.1\% of professionals utilize Sketch up for 3D modeling. Similarly, $18.3 \%$ of professionals use Revit software. Likewise, $7.5 \%$ uses Archicad, and $4.17 \%$ uses Navisworks, respectively. However, $13.3 \%$ of professionals are using other BIM software(s) in their organizations.

\section{Results}

Descriptive statistics. Descriptive statistics are used to describe the basic features of the data in a study. They provide simple summaries of the given data and form the basis of almost every quantitative data analysis through standard deviation, skewness, and kurtosis (Momeni et al., 2018). The findings of the Table exhibited that the readings of standard deviation and skewness are higher than \pm 1.5 , and values of kurtosis are more than \pm 3 . However, the mean values are between 3.5 to 3.75. This implies the collected data is following the normality pattern (Lu et al., 2020; Hair et al., 2019).

Measurement model. According to Hair et al. (2019), structural equation modeling consisted of two steps: evaluating the measurement model. We measured the model from different readings, for instance, first to examine the reliability of constructs and items. Reliability is the internal consistency of variables; it observes the relationship between other variables and how consistent they are (Taherdoost, 2016). Cronbach's alpha (CA) is a measure used to assess the reliability of measuring a construct's strength of consistency in a given set of data. The factor loading examines the reliability of individual items, and composite reliability (CR) is another good indicator to measure all the items' combined reliability. Figure 1 and Table 1 demonstrated that each item's factor loading is higher than 0.50 , and readings of CA and CR of each construct are more significant than 0.70. Thus, the condition of convergent validity was also met (Hair et al., 2019; Ahmed et al., 2020). Moreover, the findings of Table 1 and Figure 1 exhibited that the values of average variance extracted (AVE) are higher than 0.50. Hence, the pre-requisite of discriminant validity has also been met (Fornell \& Larcker, 1981). Therefore, it is confirmed that the considered hypothesized measurement model passes the initial conditions (Lu et al., 2020).

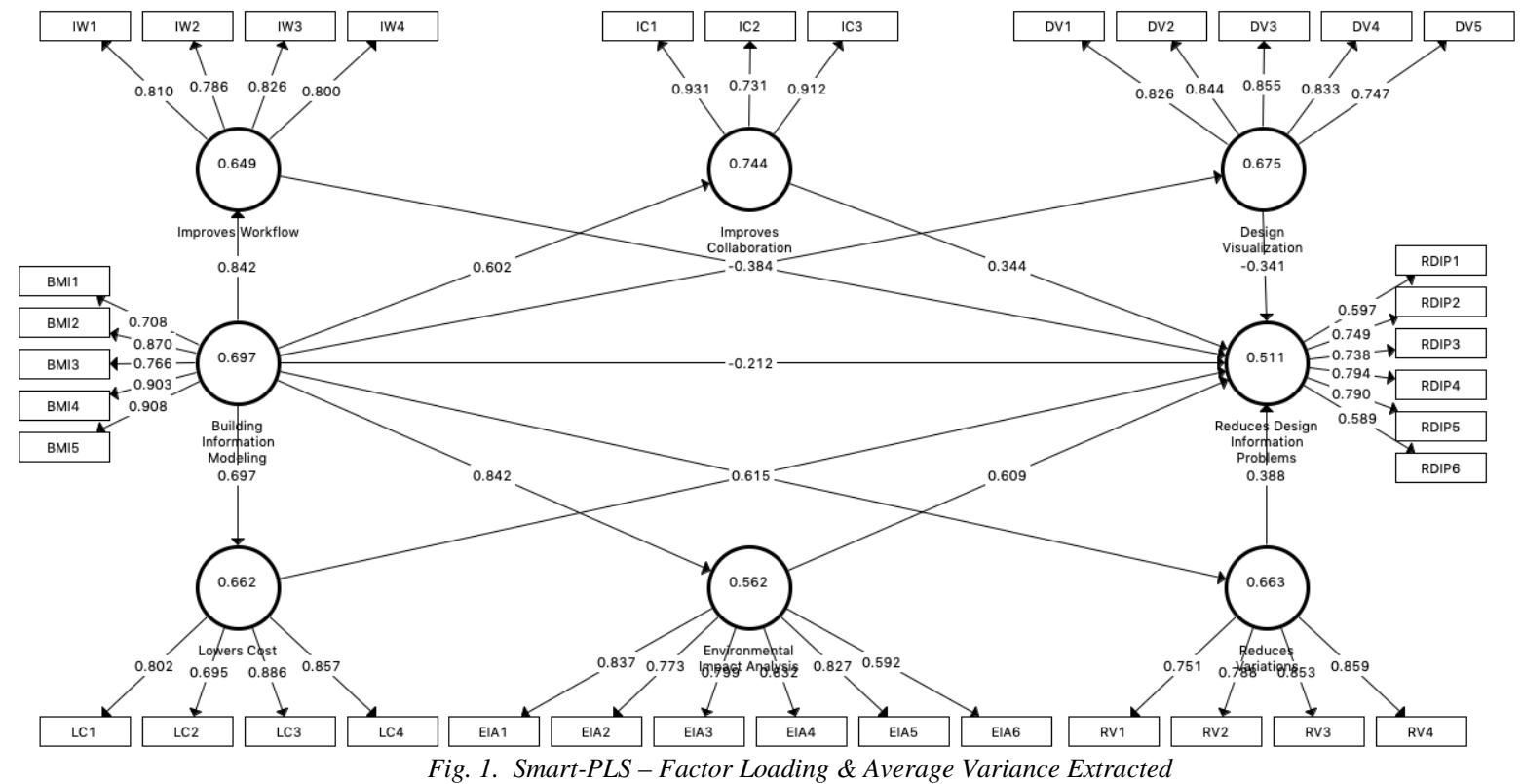


Tab. 1. Reliability and validity (Measurement model)

\begin{tabular}{|c|c|c|c|c|c|c|c|c|c|}
\hline Constructs & Items & ITM & FL & $\mathbf{C A}$ & $\mathbf{C R}$ & AVE & SD & SKW & KUR \\
\hline \multirow{5}{*}{ 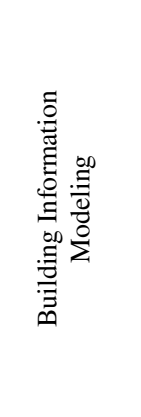 } & $\begin{array}{l}\text { BIM minimizes the risk of discrepancies between } \\
\text { plan, section, and elevation }\end{array}$ & BIM1 & 0.708 & \multirow{5}{*}{0.888} & \multirow{5}{*}{0.919} & \multirow{5}{*}{0.697} & \multirow{5}{*}{1.289} & \multirow{5}{*}{-1.039} & \multirow{5}{*}{-0.452} \\
\hline & $\begin{array}{l}\text { BIM facilitates the instant generation of new } \\
\text { sections, elevations, and } 3 \mathrm{D} \text { views }\end{array}$ & BIM2 & 0.870 & & & & & & \\
\hline & $\begin{array}{l}\text { BIM carries its ability to let AEC people (at } \\
\text { different locations) work on the same building } \\
\text { model simultaneously }\end{array}$ & BIM3 & 0.766 & & & & & & \\
\hline & $\begin{array}{l}\text { BIM is efficient for site analysis, site utilization } \\
\text { planning, and modeling the existing site conditions }\end{array}$ & BIM4 & 0.903 & & & & & & \\
\hline & $\begin{array}{l}\text { BIM reduces the time for drafting and increases for } \\
\text { design }\end{array}$ & BIM5 & 0.908 & & & & & & \\
\hline \multirow{6}{*}{ 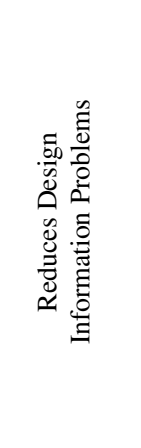 } & $\begin{array}{l}\text { Design information problems reduce by improving } \\
\text { collaboration }\end{array}$ & RDIP1 & 0.597 & \multirow{6}{*}{0.805} & \multirow{6}{*}{0.861} & \multirow{6}{*}{0.511} & \multirow{6}{*}{1.159} & \multirow{6}{*}{-1.346} & \multirow{6}{*}{-0.138} \\
\hline & $\begin{array}{l}\text { The collaboration of teams can reduce the design } \\
\text { information problem }\end{array}$ & RDIP2 & 0.749 & & & & & & \\
\hline & Cost lowering can also reduce design info. Problems & RDIP3 & 0.738 & & & & & & \\
\hline & $\begin{array}{l}\text { An improved environment can also reduce design } \\
\text { information problems }\end{array}$ & RDIP4 & 0.794 & & & & & & \\
\hline & $\begin{array}{l}\text { Project feasibility can enhance by reducing design } \\
\text { information problems }\end{array}$ & RDIP5 & 0.790 & & & & & & \\
\hline & $\begin{array}{l}\text { Design information problems always remain a } \\
\text { crucial factor for a project }\end{array}$ & RDIP6 & 0.589 & & & & & & \\
\hline \multirow{3}{*}{ 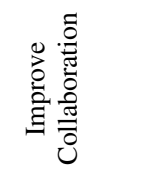 } & Reduces conflicts \& improves collaboration & IC1 & 0.931 & \multirow{3}{*}{0.821} & \multirow{3}{*}{0.896} & \multirow{3}{*}{0.744} & \multirow{3}{*}{1.163} & \multirow{3}{*}{-1.384} & \multirow{3}{*}{-0.141} \\
\hline & Reduces time waste in crosschecking documents & IC2 & 0.731 & & & & & & \\
\hline & Increases design complexity & IC3 & 0.912 & & & & & & \\
\hline \multirow{4}{*}{$\begin{array}{l}\vec{y} \\
0 \\
0 \\
0 \\
0 \\
0 \\
1\end{array}$} & Improves accuracy of construction cost projections & LC1 & 0.802 & \multirow{4}{*}{0.826} & \multirow{4}{*}{0.886} & \multirow{4}{*}{0.662} & \multirow{4}{*}{1.133} & \multirow{4}{*}{-1.449} & \multirow{4}{*}{-0.206} \\
\hline & Minimizes the risk of unexpected repair cost & $\mathrm{LC} 2$ & 0.695 & & & & & & \\
\hline & Displays anticipated operational cost & LC3 & 0.886 & & & & & & \\
\hline & Lower cost enhances the project valuation & $\mathrm{LC} 4$ & 0.857 & & & & & & \\
\hline & Reduces energy consumption & EIA1 & 0.837 & & & & & & \\
\hline & Helps in waste management & EIA2 & 0.773 & & & & & & \\
\hline $\bar{\Xi}_{\infty}$ & Produces potential hazards on projects & EIA3 & 0.799 & & & & & & \\
\hline 导 & $\begin{array}{c}\text { Environmental degradation spoils the corporate } \\
\text { image }\end{array}$ & EIA4 & 0.632 & 0.839 & 0.883 & 0.562 & 1.145 & -1.089 & -0.380 \\
\hline 氠 & $\begin{array}{l}\text { Green Environment produces internal and external } \\
\text { benefits of the project }\end{array}$ & EIA5 & 0.827 & & & & & & \\
\hline & $\begin{array}{l}\text { Environment plays a vital role in the completion of a } \\
\text { project }\end{array}$ & EIA6 & 0.592 & & & & & & \\
\hline$\cong$ & Helps in finding the most energy-efficient materials & RV1 & 0.751 & & & & & & \\
\hline 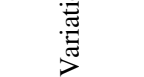 & $\begin{array}{l}\text { Helps in finding the most effective regenerative } \\
\text { design features }\end{array}$ & RV2 & 0.788 & 0834 & 0887 & 0663 & 1099 & -1077 & -0376 \\
\hline$\stackrel{0}{ٍ}$ & Integrates and updates design changes efficiently & RV3 & 0.853 & & & & & & \\
\hline 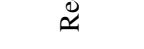 & It enhances the reliability of a project. & RV4 & 0.859 & & & & & & \\
\hline. & Stores data for 3D modelling \& software simulation & DV1 & 0.826 & & & & & & \\
\hline 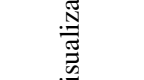 & $\begin{array}{c}\text { Produces graphical imaginaries \& makes concept } \\
\text { clearer }\end{array}$ & DV2 & 0.844 & 0870 & 012 & 0675 & 1109 & 14 & 0323 \\
\hline 要 & Produces innovative designs \& visualization tools & DV3 & 0.855 & & & & & & \\
\hline$\ddot{\omega}$ & Design visualization enhances the characteristics. & DV4 & 0.833 & & & & & & \\
\hline
\end{tabular}




\begin{tabular}{|c|c|c|c|c|c|c|c|c|c|}
\hline & $\begin{array}{l}\text { Design virtualization is an innovative hallmark that } \\
\text { increases demand. }\end{array}$ & DV5 & 0.747 & & & & & & \\
\hline \multirow{4}{*}{ 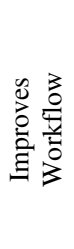 } & $\begin{array}{l}\text { More significant iteration can be embraced during } \\
\text { the design phase }\end{array}$ & IW1 & 0.810 & \multirow{4}{*}{0.821} & \multirow{4}{*}{0.881} & \multirow{4}{*}{0.649} & \multirow{4}{*}{1.116} & \multirow{4}{*}{-1.182} & \multirow{4}{*}{-0.301} \\
\hline & Reduces errors \& requires less oversight & IW2 & 0.786 & & & & & & \\
\hline & Faster project completion & IW3 & 0.826 & & & & & & \\
\hline & Enhances the quality \& speed of project & IW4 & 0.800 & & & & & & \\
\hline
\end{tabular}

The discriminant validity is evaluated through the Fornell and Larcker (1981) criterion, which offered the square root readings of AVE of each construct. The diagonal values (highlighted) of Table 2 exhibited that they are more than the correlation of other tasks of factors. Hence, the criterion of discriminant validity has been achieved, and it is validated that the measurement modified model of BIM and reducing design information problems is acceptable.

Tab. 2. The Fornell-Larcker (1981) criterion-Discriminant validity

\begin{tabular}{|c|c|c|c|c|c|c|c|c|}
\hline Constructs & BIM & DV & EIA & IC & IW & $\mathbf{L C}$ & RDIP & $\mathbf{R V}$ \\
\hline Building Information Modelling & 0.835 & & & & & & & \\
\hline Design Visualization & 0.829 & 0.822 & & & & & & \\
\hline Environmental Impact Analysis & 0.772 & 0.805 & 0.749 & & & & & \\
\hline Improves Collaboration & 0.602 & 0.737 & 0.681 & 0.862 & & & & \\
\hline Improves Workflow & 0.742 & 0.753 & 0.687 & 0.784 & 0.806 & & & \\
\hline Lowers Cost & 0.697 & 0.659 & 0.566 & 0.763 & 0.740 & 0.813 & & \\
\hline Reduces Design Information Problems & 0.673 & 0.774 & 0.661 & 0.845 & 0.742 & 0.708 & 0.715 & \\
\hline Reduces Variations & 0.784 & 0.745 & 0.588 & 0.540 & 0.780 & 0.586 & 0.674 & 0.814 \\
\hline
\end{tabular}

The findings of Table 3 exhibited that the readings of the Heterotrait-Monotrait (HTMT) ratio of correlation are less than 0.85 (Henseler et al., 2015). Thus, both discriminant and convergent validities criteria have been achieved. Therefore, it is established that our considered measurement model for BIM and reduces design information problems is validated.

Tab. 3. Heterotrait-Monotrait (HTMT) Ratio

\begin{tabular}{|l|l|l|l|l|l|l|l|l|}
\hline Constructs & BIM & DV & EIA & IC & IW & LC & RDIP & RV \\
\hline Building Information Modelling & & & & & & & & \\
\hline Design Visualization & 0.821 & & & & & & & \\
\hline Environmental Impact Analysis & 0.754 & 0.744 & & & & & & \\
\hline Improves Collaboration & 0.700 & 0.786 & 0.766 & & & & & \\
\hline Improves Workflow & 0.761 & 0.618 & 0.654 & 0.755 & & & & \\
\hline Lowers Cost & 0.605 & 0.709 & 0.722 & 0.632 & 0.721 & & & \\
\hline Reduces Design Information Problems & 0.794 & 0.600 & 0.554 & 0.511 & 0.799 & 0.779 & & \\
\hline Reduces Variations & 0.674 & 0.633 & 0.697 & 0.635 & 0.699 & 0.687 & 0.643 & \\
\hline
\end{tabular}

Structural model. The second phase of analyzes is to evaluate the considered structural model. Thus, we generated R-square values, path co-efficient analyzes, SRMR measurement, and predictive relevance $\left(Q^{2}\right)$ readings to validate the considered structural model (Ahmed et al., 2019). The findings of Table 4 demonstrated the R-square readings of different endogenous factors, also known as the goodness of fit of the structural model. The outcomes of Table 4 and Figure 2 showed that design visualization experienced a $68.7 \%$ change due to its respective exogenous variables. Similarly, environmental impact analysis experienced 70.9\%, improves collaboration felt $36.3 \%$, improve workflow having $70.8 \%$, lower-cost felt $48.5 \%$ changes due to their respective exogenous factors. Similarly, reduces variation faced $88.2 \%$, and reducing design information problems experienced $78.1 \%$ change due to their respective exogenous variables. Hence, the R-square readings validated the structural model's fitness for BIM and reducing design information problems. 


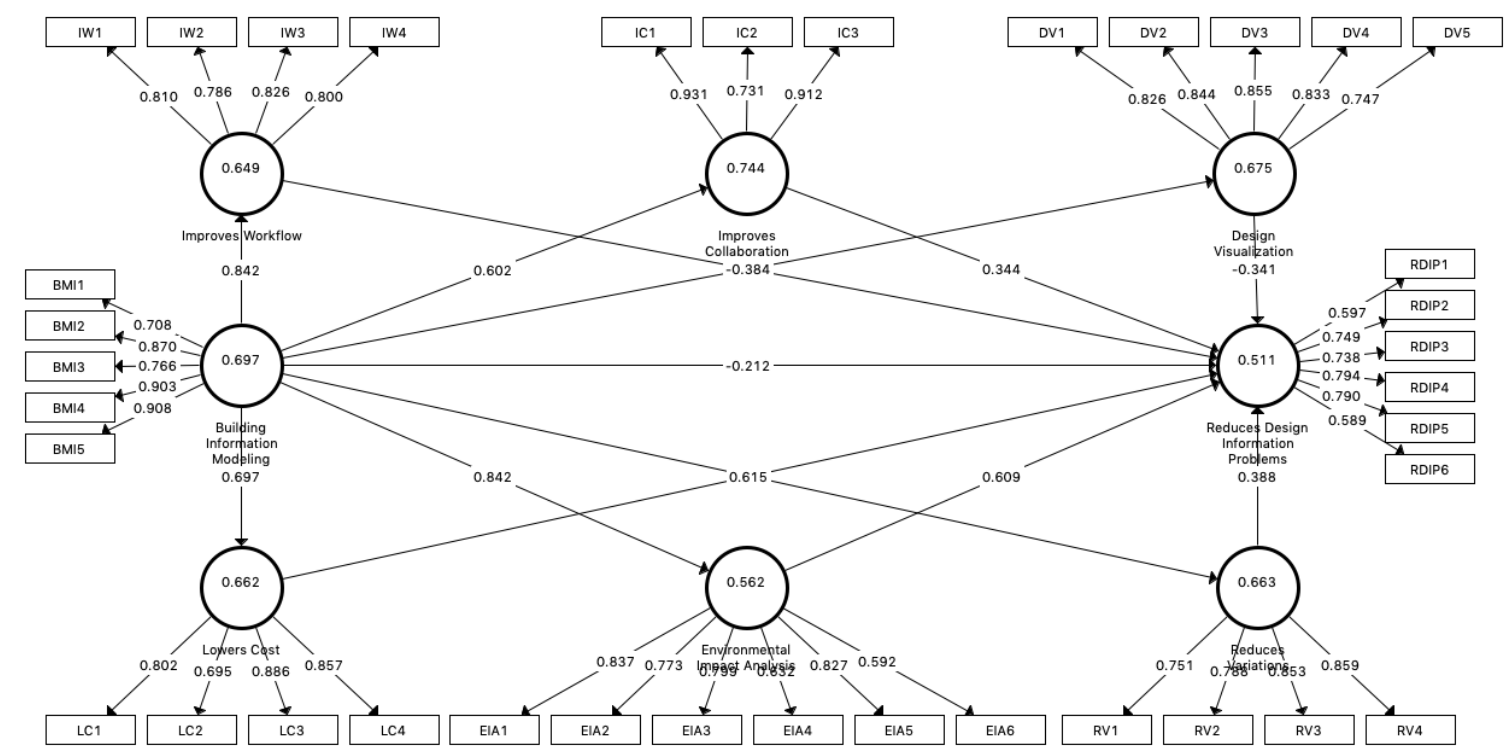

Fig. 2. Smart-PLS - Path Analyses

Tab. 4. R-Square values

\begin{tabular}{|c|c|c|}
\hline Constructs & R Square & R Square Adjusted \\
\hline Design Visualization & 0.687 & 0.686 \\
\hline Environmental Impact Analysis & 0.709 & 0.708 \\
\hline Improves Collaboration & 0.363 & 0.361 \\
\hline Improves Workflow & 0.708 & 0.708 \\
\hline Lowers Cost & 0.485 & 0.484 \\
\hline Reduces Design Information Problems & 0.882 & 0.880 \\
\hline Reduces Variations & 0.781 & 0.780 \\
\hline
\end{tabular}

Postulated direct association. We have evaluated the direct connotation between the variables in two steps; first, we assessed the association of BIM with its constituents, such as improving workflow, improving collaboration, design visualization, lower cost, environmental impact analysis, and reducing variations. Additionally, we also checked the impact of BIM in reducing design information problems. The findings of Table 5 and Figure 2 exhibited that BIM has a significant and positive association between improving workflow, improving collaboration, design visualization, lowering cost, environmental impact analysis, and reducing variations $(T> \pm 1.96 \& \mathrm{p}<0.01)$. The results also confirmed that BIM has a significant impact in reducing design information problems. The negative impact (-0.174) showed that BIM is reducing the design information problems. The second step of direct association is evaluating the effect of individual constituents of BIM, such as improving workflow, improving collaboration, design visualization, lower cost, environmental impact analysis, and reducing variations in design information problems reduction. The outcomes of Table 5 and Figure 2 demonstrated that improving workflow, improving collaboration, design visualization, lower cost, environmental impact analysis, and reducing variations have a significant impact in reducing design information problems $(\mathrm{T}> \pm 1.96 \& \mathrm{p}<0.01)$. Thus, it is finally concluded that hypotheses H1 to H13 are substantiated because of the corresponding sig. values are less than 0.01 .

Tab. 5. Postulated direct association

\begin{tabular}{|c|c|c|c|c|c|}
\hline Hypotheses & $\begin{array}{c}\text { Hypothesized Direct } \\
\text { Relationship }\end{array}$ & SRW & T Statistics & P Values & Decisions \\
\hline H1: & BIM $\rightarrow$ DV & 0.830 & 41.778 & 0.000 & Supported \\
\hline H2: & BIM $\rightarrow$ EIA & 0.842 & 49.471 & 0.000 & Supported \\
\hline H3: & BIM $\rightarrow$ IC & 0.602 & 14.634 & 0.000 & Supported \\
\hline H4: & BIM $\rightarrow$ IW & 0.843 & 44.417 & 0.000 & Supported \\
\hline H5: & BIM $\rightarrow$ LC & 0.695 & 20.469 & 0.000 & Supported \\
\hline H6: & BIM $\rightarrow$ RDIP & -0.174 & 1.969 & 0.049 & Supported \\
\hline H7: & BIM $\rightarrow$ RV & 0.886 & 101.758 & 0.000 & Supported \\
\hline
\end{tabular}




\begin{tabular}{|c|c|c|c|c|c|}
\hline H8: & DV $\rightarrow$ RDIP & -0.438 & 4.256 & 0.000 & Supported \\
\hline H9: & EIA $\rightarrow$ RDIP & 0.608 & 4.751 & 0.000 & Supported \\
\hline H10: & IC $\rightarrow$ RDIP & 0.367 & 4.434 & 0.000 & Supported \\
\hline H11: & IW $\rightarrow$ RDIP & -0.406 & 3.924 & 0.000 & Supported \\
\hline H12: & LC $\rightarrow$ RDIP & 0.696 & 15.198 & 0.000 & Supported \\
\hline H13: & RV $\rightarrow$ RDIP & 0.359 & 6.356 & 0.000 & Supported \\
\hline
\end{tabular}

Note: Null Hypotheses Rejected at $* * p<0.01$; SRW: Standardized Regression Weights

Mediation analyses. From Figure 1, it is evident that BIM has a direct association with individual factors such as improving workflow, improving collaboration, design visualization, lowering cost, environmental impact analysis, and reducing variations. Additionally, BIM has a significant impact in reducing design information problems. Figure 2 also demonstrated an indirect association between BIM and reducing design information problems with the help of BIM elements (improve workflow, improve collaboration, design visualization, lower cost, environmental impact analysis, and reduces variations). We examined the mediation using bootstrapping method (Hayes \& Rockwood, 2020) and evaluated Table 6. The outcomes showed that elements, such as improving workflow, improving collaboration, design visualization, lower cost, environmental impact analysis, and reducing variations, have a significant mediation between BIM and reducing design information problems. Thus, it is finally concluded that the hypotheses H14A to H14F are substantiated, and design information problems reduction not only had a significant direct impact through BIM and its constituents but also have a partial mediation through improve workflow, improve collaboration, design visualization, lower cost, environmental impact analysis, and reduces variations.

Tab. 6. Mediation analysis

\begin{tabular}{|c|c|c|c|c|c|c|}
\hline \multirow{2}{*}{ Hypotheses } & $\begin{array}{c}\text { Mediation } \\
\text { Path Analyses }\end{array}$ & $\begin{array}{c}\text { Path } \\
\text { Coefficient }\end{array}$ & $\begin{array}{c}\text { T } \\
\text { Statistics }\end{array}$ & \multirow{2}{*}{$\begin{array}{c}\text { P** } \\
\text { Values }\end{array}$} & \multicolumn{2}{|c|}{ BCCI } \\
\cline { 5 - 8 } & $\mathrm{BIM} \rightarrow \mathrm{DV} \rightarrow \mathrm{RDIP}$ & -0.364 & 4.111 & 0.000 & -0.547 & $\mathbf{9 7 . 5 \%}$ \\
\hline $\mathrm{H} 14 \mathrm{~A}$ & $\mathrm{BIM} \rightarrow \mathrm{EIA} \rightarrow \mathrm{RDIP}$ & 0.512 & 4.641 & 0.000 & 0.296 & 0.720 \\
\hline $\mathrm{H} 14 \mathrm{~B}$ & $\mathrm{BIM} \rightarrow \mathrm{IC} \rightarrow \mathrm{RDIP}$ & 0.221 & 4.308 & 0.000 & 0.130 & 0.326 \\
\hline $\mathrm{H} 14 \mathrm{C}$ & $\mathrm{BIM} \rightarrow \mathrm{IW} \rightarrow \mathrm{RDIP}$ & -0.342 & 4.037 & 0.000 & -0.488 & -0.178 \\
\hline $\mathrm{H} 14 \mathrm{D}$ & $\mathrm{BIM} \rightarrow \mathrm{LC} \rightarrow \mathrm{RDIP}$ & 0.484 & 12.584 & 0.000 & 0.411 & 0.558 \\
\hline $\mathrm{H} 14 \mathrm{E}$ & $\mathrm{BIM} \rightarrow \mathrm{RV} \rightarrow \mathrm{RDIP}$ & 0.318 & 6.364 & 0.000 & 0.227 & 0.424 \\
\hline $\mathrm{H} 14 \mathrm{~F}$ & & & & &
\end{tabular}

Stone-Geisser $\left(Q^{2}\right)$ and SRMR indicator. The findings of Table 7 demonstrated the predictive values, i.e., Stone-Geisser $\left(\mathrm{Q}^{2}\right)$ readings, which revealed all the predictive relevance $\left(\mathrm{Q}^{2}\right)$ followed the cut-off values and validated the predictive relevance of every endogenous model such as DV, EIA, IC, IW, LC, RV, \& RDIP $(0.297,0.255,0.327,0.441,0.302,0.757, \& 0.324$ correspondingly), and distinctive independent factors. Additionally, the findings of Table 8 specified the SRMR indicator that also confirmed the goodness of fit of the structural model.

Tab. 7. Stone-Geisser $\left(Q^{2}\right)$

\begin{tabular}{|c|c|}
\hline Constructs & Q $^{2}$ Predict \\
\hline BIM & \\
\hline DV & 0.297 \\
\hline EIA & 0.255 \\
\hline IC & 0.327 \\
\hline IW & 0.441 \\
\hline LC & 0.302 \\
\hline RV & 0.757 \\
\hline RDIP & 0.324 \\
\hline
\end{tabular}

Tab. 8. SRMR Indicator

\begin{tabular}{|c|c|}
\hline Saturated Model & Estimated Model \\
\hline 0.052 & 0.096 \\
\hline
\end{tabular}


Eigenvalues. These eigenvalues are related to the canonical correlation between variables and explains how much variance is in the data in that direction. The findings of Table 9 exhibited that the percentage of the variance is the proportion of discriminating ability of the 37 items found in a given function. This proportion is calculated as the proportion of the function's eigenvalue to the sum of all eigenvalues. For this case, the function accounts for $100 \%$ of the discriminating ability of the discriminating variable (Lu et al., 2020). The functions are included in a given test and account for the hypothesis that the canonical correlations associated with the function are equal to zero.

Tab. 9. Eigenvalues

\begin{tabular}{|c|c|c|c|c|}
\hline Function & Eigenvalue & \% of Variance & Cumulative \% & Canonical Correlation \\
\hline 1 & $.260^{\mathrm{a}}$ & 100.0 & 100.0 & .454 \\
\hline
\end{tabular}

Note: a. First 1 canonical discriminant functions were used in the analysis

Wilks' Lambda test. Wilk Lambda is a probability distribution that evaluates the differences between two or more groups on multiple variables at one time. It tells how well each level of independent variable contributes to the model. The value ranges from 0 to 1 , where 0 means total discrimination and 1 means no discrimination (Hair et al., 2019). Table 10 shows Wilk's Lambda values associated with the level of statistical significance or p-value. In a multivariate normal distribution, the F-test statistics is one-way ANOVA, which examines the differences between multiple groups on one variable. In other words, the acceptance or rejection of the hypothesis, in this case, all the significance values are greater than 0.001 . Hence hypothesis is accepted. A Predictive Discriminant Analysis was carried on the perceived variables comprising 37 items. Wilk's Lambda Test was carried out to find out whether a certain predictor variable in a model is significant or not (Ahmed et al., 2020). It will reject the hypothesis if the corresponding coefficient being zero. From the sample of 600, 523 participants responded to the questionnaire successfully. The evidence was found that almost all variables have a significance p-value greater than 0.01 . Hence the hypothesis is accepted, which states that:

Hypothesis: BIM has a significant impact in reducing design information problems

Hence, this suggests that BIM has a significant impact in reducing design information problems on construction projects through improved collaboration, lowered cost, environmental impact analysis, reduced variations, design visualization, and improved workflow.

Tab. 10. Tests of Equality of Group Means

\begin{tabular}{|c|c|c|c|c|c|c|}
\hline Constructs & Items & Wilks' Lambda & $\mathbf{F}$ & Df1 & Df2 & Sig. \\
\hline \multirow{5}{*}{ 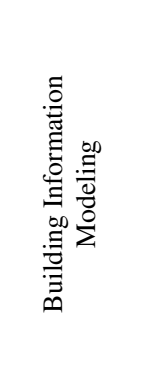 } & $\begin{array}{l}\text { BIM minimizes the risk of discrepancies between plan, } \\
\text { section, and elevation }\end{array}$ & .930 & 8.838 & 1 & 521 & .004 \\
\hline & $\begin{array}{l}\text { BIM facilitates the instant generation of new sections, } \\
\text { elevations, and 3D views }\end{array}$ & .989 & 1.261 & 1 & 521 & .264 \\
\hline & $\begin{array}{c}\text { BIM carries its ability to let AEC people (at different } \\
\text { locations) work on the same building model } \\
\text { simultaneously }\end{array}$ & .996 & .431 & 1 & 521 & .513 \\
\hline & $\begin{array}{l}\text { BIM is efficient for site analysis, site utilization planning, } \\
\text { and modeling the existing site conditions }\end{array}$ & .935 & 8.216 & 1 & 521 & .005 \\
\hline & BIM reduces the time for drafting and increases for design & .986 & 1.720 & 1 & 521 & .192 \\
\hline \multirow{6}{*}{ 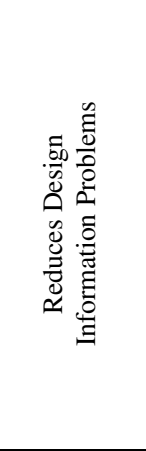 } & $\begin{array}{l}\text { Design information problems reduce by improving } \\
\text { collaboration }\end{array}$ & .959 & 5.052 & 1 & 521 & .026 \\
\hline & $\begin{array}{l}\text { The collaboration of teams can reduce the design } \\
\text { information problem }\end{array}$ & .961 & 4.812 & 1 & 521 & .030 \\
\hline & Cost lowering can also reduce design info. Problems & .955 & 5.614 & 1 & 521 & .019 \\
\hline & $\begin{array}{l}\text { An improved environment can also reduce design } \\
\text { information problems }\end{array}$ & .911 & 11.502 & 1 & 521 & .001 \\
\hline & $\begin{array}{l}\text { Project feasibility can enhance by reducing design } \\
\text { information problems }\end{array}$ & .974 & 3.194 & 1 & 521 & .076 \\
\hline & $\begin{array}{l}\text { Design information problems always remain a crucial } \\
\text { factor for a project }\end{array}$ & .963 & 4.534 & 1 & 521 & .035 \\
\hline \multirow{3}{*}{ 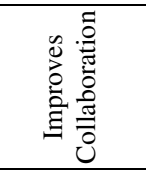 } & Reduces conflicts \& improves collaboration & .961 & 4.811 & 1 & 521 & .030 \\
\hline & Reduces time waste in crosschecking documents & .972 & 3.436 & 1 & 521 & .066 \\
\hline & Increases design complexity & .931 & 8.806 & 1 & 521 & .004 \\
\hline 芯 & Improves accuracy of construction cost projections & .979 & 2.507 & 1 & 521 & .116 \\
\hline
\end{tabular}




\begin{tabular}{|c|c|c|c|c|c|c|}
\hline & Minimizes the risk of unexpected repair cost & .932 & 8.451 & 1 & 521 & 0.005 \\
\hline & Displays anticipated operational cost & .965 & 4.712 & 1 & 521 & .020 \\
\hline & Lower cost enhances the project valuation & .932 & 8.903 & 1 & 521 & .003 \\
\hline \multirow{6}{*}{ 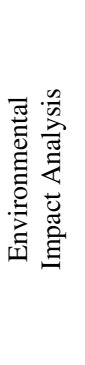 } & Reduces energy consumption & .971 & 2.606 & 1 & 521 & .105 \\
\hline & Helps in waste management & .911 & 9.786 & 1 & 521 & .002 \\
\hline & Produces potential hazards on projects & .922 & 8.456 & 1 & 521 & .003 \\
\hline & Environmental degradation spoils the corporate image. & .943 & 5.675 & 1 & 521 & .012 \\
\hline & $\begin{array}{l}\text { Green Environment produces internal and external } \\
\text { benefits of the project }\end{array}$ & .964 & 4.812 & 1 & 521 & .020 \\
\hline & $\begin{array}{c}\text { Environment plays a vital role in the completion of a } \\
\text { project }\end{array}$ & .978 & 3.299 & 1 & 521 & .075 \\
\hline \multirow{4}{*}{ 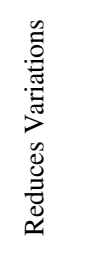 } & Helps in finding the most energy-efficient materials & .977 & 3.693 & 1 & 521 & .084 \\
\hline & $\begin{array}{l}\text { Helps in finding the most effective regenerative design } \\
\text { features }\end{array}$ & .965 & 4.711 & 1 & 521 & .010 \\
\hline & Integrates and updates design changes efficiently & .967 & 4.511 & 1 & 521 & .020 \\
\hline & It enhances the reliability of a project. & .923 & 8.457 & 1 & 521 & .004 \\
\hline \multirow{5}{*}{ 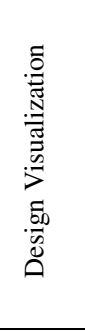 } & Stores data for 3D modeling \& software simulation & .946 & 5.672 & 1 & 521 & .022 \\
\hline & Produces graphical imaginaries \& makes concept clearer & .977 & 3.693 & 1 & 521 & .084 \\
\hline & Produces innovative designs \& visualization tools & .993 & 1.922 & 1 & 521 & .291 \\
\hline & Design visualization enhances the characteristics & .955 & 5.614 & 1 & 521 & .019 \\
\hline & $\begin{array}{l}\text { Design virtualization is an innovative hallmark that } \\
\text { increases demand }\end{array}$ & .966 & 4.910 & 1 & 521 & .047 \\
\hline \multirow{4}{*}{$\begin{array}{l}3 \\
0 \\
\frac{1}{2} \\
\vdots \\
\vdots \\
3 \\
0 \\
0 \\
0 \\
0 \\
\vdots \\
\vdots\end{array}$} & $\begin{array}{l}\text { More significant iteration can be embraced during the } \\
\text { design phase }\end{array}$ & .987 & 1.821 & 1 & 521 & .287 \\
\hline & Reduces errors \& requires less oversight & .949 & 4.677 & 1 & 521 & .029 \\
\hline & Faster project completion & .939 & 6.786 & 1 & 521 & .089 \\
\hline & Enhances the quality \& speed of project & .948 & 4.673 & 1 & 521 & .019 \\
\hline
\end{tabular}

\section{Discussion}

The undertaken study evaluates the influence of BIM while examining the design information quality. In this context, we employed structural equation modeling \& multivariate analysis and tested the hypotheses. The findings of the Table exhibited that the readings of standard deviation and skewness are implied the collected data is following the normality pattern ( $\mathrm{Lu}$ et al., 2020; Hair et al., 2019). First, we have evaluated the direct connotation between the variables in two steps; first, we assessed the association of BIM with its constituents, such as improving workflow, improving collaboration, design visualization, lower cost, environmental impact analysis, and reducing variations. Additionally, we also checked the impact of BIM in reducing design information problems. The findings exhibited that BIM has a significant and positive association between improving workflow, improving collaboration, design visualization, lowering cost, environmental impact analysis, and reducing variations. These findings are consistent with the previous literature that also exhibited similar outcomes (Yap \& Skitmore, 2018; Al Hattab \& Hamzeh, 2016; Guo \& Ma, 2021; Olawumi \& Chan, 2018; Yassin et al., 2020; Burggräf et al., 2019; Chen et al., 2020b; Bradley et al., 2016). The results also confirmed that BIM has a significant impact in reducing design information problems. The negative impact showed that BIM is reducing the design information problems. These findings are consistent with the previous literature (Sampaio, 2017; Oldfield et al., 2017; Troiani et al., 2020; Doumbouya et al., 2016; Dai et al., 2018; Donato et al., 2018; Dahmani et al., 2021).

The second step of direct association is evaluating the effect of individual constituents of BIM, such as improving workflow, improving collaboration, design visualization, lower cost, environmental impact analysis, and reducing variations in design information problems reduction. Previous literature also exhibited that the outcomes demonstrated that improving workflow, improving collaboration, design visualization, lower cost, environmental impact analysis, and reducing variations have a significant impact in reducing design information 
problems Son et al., 2017; Feng \& Chen, 2019; Chen et al., 2020a; Rezaei et al., 2019; Son et al., 2019; Gbadamosi et al., 2019; Petrova et al., 2017; Pełczyński et al., 2021; Suryanto et al., 2016; Röck et al., 2018a). The indirect effect (mediation) findings demonstrated that elements, such as improving workflow, improving collaboration, design visualization, lower cost, environmental impact analysis, and reducing variations, have a significant mediation between BIM and reducing design information problems. These results are also confirmed the previous literature, such as Konigsberg and Frankenberg (2018), Al Mousli and El-Sayegh (2016), Mollasalehi et al. (2017), Al Hattab and Hamzeh (2015), Arshad et al. (2017), Röck et al. (2018b), Sakin and Kiroglu (2017), Petrova et al. (2017), and Bergonzoni et al. (2021).

\section{Conclusions}

The focus of this research is to study the impact of BIM in assessing design information quality. Consequently, the study well concluded that BIM has a significant impact in assessing design information quality through the processes, such as improves collaboration by reducing conflict between team members and reducing time in crosschecking documents, resulting in reduced design information problems. Lowers cost by predicting accuracy in cost projections, displaying anticipated operational cost, and minimizing the risk of unexpected repair costs. Thus, it may ultimately reduce design information problems-environmental impact analysis through reducing balanced energy consumption and waste management. Thus, resulting in decreased design information problems. Reduces variations by finding the most energy-efficient materials, useful regenerative design features, and effectively integrating changes into the design. Hence, minimizing design information problems significantly. Design visualization through $3 \mathrm{D}$ modeling and software simulation, and producing innovative designs and visualization tools. Thus, significantly reducing design information problems. Improves workflow through embracing more significant iteration in the design phase, reducing errors, and faster project completion. Thus, resulting in decreased design information problems. This research's primary focus is to evaluate the design information quality through BIM implementation on construction projects in Pakistan. A literature review revealed design information management, problems, possible solutions, the vision of BIM, and its application in the construction industry to overcome information requirements' challenges.

This study emphasizes the ability of BIM to facilitate the management of project information and process, including its dynamic exemplifications. We can conclude a significant relationship between exogenous and endogenous variables from the data analysis and obtained results. The structural equation modeling verified that variables like improve workflow, design visualization, and variations have a meaningful negative relationship with design information problems. However, other exogenous variables, collaboration, cost, and EIA, depict a positive and significant relationship, which is also considered negative. This means that the design information problems can be significantly decreased by implementing BIM on construction projects. Therefore, the independent variables have a significant bond with the dependent variable (RDIP), aiming to design information quality on projects in a nutshell. This is essential for construction industry professionals who seek to mitigate the consequences of design complexity on quality, economy, and schedule of construction projects through BIM implementation. For future work, there's a great potential of BIM for assessing the information quality challenges concerning architectural and mechanical, electrical, and plumbing (MEP) systems, system branches, and their members' connectivity. Similarly, more research can be done on automated assessment of design information management in different construction industry sectors. Lastly, future research can evaluate the impact of design information for project operation and maintenance phases through BIM application.

The undertaken study has certain limitations. For instance, the sample size is limited; thus, for more generalizable and robust results, a higher sample size should be taken, and it is recommended that future researchers take a higher sample for more robust outcomes. Another limitation of the undertaken study is the statistical modeling that does not examine the cause and effect between the variables. Therefore, it is recommended that future researchers incorporate more sophisticated models, which can evaluate the cause and effect between the variable. Finally, this research is conducted in Pakistan, and the results cannot be generalized to other regional countries. Thus, it is recommended the future researchers conduct a similar study by taking regional countries for more robust outcomes.

\section{References}

Ahmed, R. R., Hussain, S., Pahi, M. H., Usas, A., \& Jasinskas, E. (2019). Social media handling and Extended Technology Acceptance Model (ETAM): Evidence from SEM-based multivariate approach. Transformations in Business \& Economics, 18(3), 246-271.

Ahmed, R. R., Romeika, G., Kauliene, R., Streimikis, J., \& Dapkus, R. (2020). ES-QUAL Model and customer satisfaction in online banking: Evidence from multivariate analysis techniques. Oeconomia Copernicana, 11(1), 55-89. http://dx.doi.org/10.24136/oc.2020.003 
Al Hattab, M., \& Hamzeh, F. (2015). Using social network theory and simulation to compare traditional versus BIM-lean practice for design error management. Automation in Construction, 52, 59-69. https://doi.org/10.1016/j.autcon.2015.02.014

Al Hattab, M., \& Hamzeh, F. (2016). Analyzing design workflow: An agent-based modeling approach. Procedia Engineering, 164, 510-517. https://doi.org/10.1016/j.proeng.2016.11.652

Al Hattab, M., \& Hamzeh, F. (2018). Simulating the dynamics of social agents and information flows in BIMbased design. Automation in Construction, 92, 1-22. https://doi.org/10.1016/j.autcon.2018.03.024

Al Mousli, M. H., \& El-Sayegh, S. M. (2016). Assessment of the design-construction interface problems in the UAE. Architectural Engineering and Design Management, 12(5), 353-366.

Aladag, H., Demirdögen, G., \& Isık, Z. (2016). Building information modeling (BIM) use in Turkish construction industry. Procedia Engineering, 161, 174-179.

Andújar-Montoya, M. D., Galiano-Garrigós, A., Rizo-Maestre, C., \& Echarri-Iribarren, V. (2019). BIM and lean construction interactions: A state-of-the-art review. WIT Transactions on the Built Environment, 192, 113.

Arshad, R., Zahoor, S., Shah, M. A., Wahid, A., \& Yu, H. (2017). Green IoT: An investigation on energy-saving practices for 2020 and beyond. IEEE Access, 5,15667-15681.

Baskakov, K. O. (2019). Prospects of using BIM-technologies in assessing the effectiveness of investment projects in construction. BIM in Construction \& Architecture, 2019, 238-242. https://doi.org/10.23968/bimac.2019.044

Bekdik, B., Pörzgen, J., Bull, S. S., \& Thuesen, C. (2018). Modularising design processes of façades in Denmark: re-exploring the use of design structure matrix. Architectural Engineering and Design Management, 14(1-2), 95-108.

Bell, E., Bryman, A., \& Harley, B. (2018). Business research methods. United Kingdom: Oxford University Press.

Bergonzoni, G., Marino, V., Elagiry, M., \& Costa, A. (2021). Assessing residential buildings compliance with sustainability rating systems through a BIM-Based approach. In Multidisciplinary Digital Publishing Institute Proceedings, 65(1), 22-31.

Bradley, A., Li, H., Lark, R., \& Dunn, S. (2016). BIM for infrastructure: An overall review and constructor perspective. Automation in Construction, 71,139-152.

Burggräf, P., Dannapfel, M., Schneidermann, D., Esfahani, M. E., \& Schwamborn, N. (2019). Integrated factory modeling: Using BIM to disrupt the interface between manufacturing and construction in factory planning. WIT Transactions on the Built Environment, 192, 143-155.

Chen, Q., Adey, B. T., Haas, C., \& Hall, D. M. (2020a). Using look-ahead plans to improve material flow processes on construction projects when using BIM and RFID technologies. Construction Innovation, 20(3), 471-508. https://doi.org/10.1108/ci-11-2019-0133

Chen, Q., Hall, D. M., Adey, B. T., \& Haas, C. T. (2020b). Identifying enablers for coordination across construction supply chain processes: a systematic literature review. Engineering, Construction and Architectural Management, 28(4), 1083-1113. https://doi.org/10.1108/ecam-05-2020-0299

Chu, Z., Xu, Z., \& Xie, F. (2019). Experimental evaluation of overlapping strategy for the multimode resourceconstrained project scheduling problem. Arabian Journal for Science and Engineering, 44(3), 2503-2517.

Dahmani, N., Belhadi, A., Benhida, K., Elfezazi, S., Touriki, F. E., \& Azougagh, Y. (2021). Integrating lean design and eco-design to improve product design: From literature review to an operational framework. Energy \& Environment. https://doi.org/10.1177/0958305x21993481

Dai, C., Hao, D., Zuo, Z., Zhao, H., \& Shang, Z. (2018). Exploration application of BIM technology on artificial island engineering. IOP Conference Series: Earth and Environmental Science, 171. https://doi.org/10.1088/1755-1315/171/1/012022

Donato, V., Lo-Turco, M., \& Bocconcino, M. M. (2018). BIM-QA/QC in the architectural design process. Architectural Engineering and Design Management, 14(3), 239-254.

Doumbouya, L., Gao, G., \& Guan, C. (2016). Adoption of the Building Information Modeling (BIM) for construction project effectiveness: The review of BIM benefits. American Journal of Civil Engineering and Architecture, 4(3), 74-79.

Feng, C-W., \& Chen, C-W. (2019). Using BIM and MR to improve the process of job site construction and inspection. Building Information Modeling (BIM) in Design, Construction and Operations III, 192(12), 21-32. https://doi.org/10.2495/bim190031

Fornell, C., \& Larker, D. (1981). Structural equation modeling and regression: Guidelines for research practice. Journal of Marketing Research, 18(1), 39-50. https://doi.org/10.1177/002224378101800313

Frefer, A. A., Mahmoud, M., Haleema, H., \& Almamlook, R. (2018). Overview success criteria and critical success factors in project management. Industrial Engineering \& Management, 7(1), 1000244. https://doi.org/10.4172/2169-0316.1000244 
Gbadamosi, A-Q., Mahamadu, A-M., Oyedele, L. O., Akinade, O. O., Manu, P., Mahdjoubi, L., \& Aigbavboa, C. (2019). Offsite construction: Developing a BIM-based optimizer for assembly. Journal of Cleaner Production, 215, 1180-1190. https://doi.org/10.1016/j.jclepro.2019.01.113

Gogtay, N. J., \& Thatte, U. M. (2017). Principles of correlation analysis. Journal of the Association of Physicians of India, 65(3), 78-81.

Guo, J., Liu, J., Wang, J., \& Deng, X. (2019). Research on the application of BIM technology in whole process cost management. IOP Conference Series: Earth and Environmental Science, 242. https://doi.org/10.1088/1755-1315/242/6/062081

Guo, W., \& Ma, J. (2021). BIM Process and application in geological exploration of rail transit engineering in mountainous cities. IOP Conference Series: Earth and Environmental Science, 669(1). https://doi.org/10.1088/1755-1315/669/1/012009

Hair, J., Risher, J., Sarstedt, M., \& Ringle, C. (2019). When to use and how to report the results of PLS-SEM. European Business Review, 31(1), 2-24. https://doi.org/10.1108/ebr-11-2018-0203

Hayes, A. F., \& Rockwood, N. J. (2020). Conditional process analysis: Concepts, computation, and advances in modeling of the contingencies of mechanisms. American Behavioral Scientist, 64(1), 19-54. https://doi.org/10.1177/0002764219859633

Heaton, J., Parlikad, A. K., Owens, D., \& Pawsey, N. (2019). BIM as an enabler for digital transformation. In International Conference on Smart Infrastructure and Construction 2019 (ICSIC) Driving data-informed decision-making, 49-54. ICE Publishing. https://doi.org/10.1680/icsic.64669.049

Henseler, J., Ringle, C. M., \& Sarstedt, M. (2015). A new criterion for assessing discriminant validity in variance-based structural equation modeling. Journal of the Academy of Marketing Science, 43(1), 115135. https://doi.org/10.1007/s11747-014-0403-8

Juszczyk, M., Tomana, A., \& Bartoszek, M. (2016). Current issues of BIM-based design change management, analysis and visualization. Procedia Engineering, 164, 518-525. https://doi.org/10.1016/j.proeng.2016.11.653

Khilnani, A. K. (2018). Translation and validation of tinnitus handicap inventory into Gujarati language. International Journal of Otorhinolaryngology and Head and Neck Surgery, 4(3), 730. https://doi.org/10.18203/issn.2454-5929.ijohns20181861

Konigsberg, L. W., \& Frankenberg, S. R. (2018). Typicality and predictive distributions in discriminant function analysis. Human Biology, 90(1), 31-44.

Li, S., \& Yu, Y. (2019). Application of BIM technology in calculation of a residential building. IOP Conference Series: Earth and Environmental Science, 330. https://doi.org/10.1088/1755-1315/330/2/022071

Lin, C. L., \& Jeng, C. H. (2017). Exploring interface problems in Taiwan's construction projects using structural equation modeling. Sustainability, 9(5), 822. https://doi.org/10.3390/su9050822

Long, M., Li, Q., \& Guo, Y. (2019). Application mode analysis and adaptive design exploration of BIM technology. In Journal of Physics: Conference Series, 1345(5), 052036. IOP Publishing. https://doi.org/10.1088/1742-6596/1345/5/052036

Lu, J., Ren, L., Zhang, C., Rong, D., Ahmed, R. R., \& Streimikis, J. (2020). Modified Carroll's pyramid of corporate social responsibility to enhance organizational performance of SMEs industry. Journal of Cleaner Production, 271, 1-18. https://doi.org/10.1016/j.jclepro.2020.122456

Mahamadu, A-M., Mahdjoubi, L., \& Booth, C. A. (2017). Critical BIM qualification criteria for construction pre-qualification and selection. Architectural Engineering and Design Management, 13(5), 326-343. https://doi.org/10.1080/17452007.2017.1296812

Mahamadu, A-M., Mahdjoubi, L., Booth, C., Manu, P., \& Manu, E. (2019). Building information modelling (BIM) capability and delivery success on construction projects. Construction Innovation, 19(2), 170-192. https://doi.org/10.1108/ci-03-2018-0016

Mahamadu, A-M., Manu, P., Mahdjoubi, L., Booth, C., Aigbavboa, C., \& Abanda, F. H. (2019). The importance of BIM capability assessment. Engineering, Construction and Architectural Management, 27(1), 24-48. https://doi.org/10.1108/ecam-09-2018-0357

Mahmudin, C., Sumarmo, U., \& Kustiana, A. (2020). The effect of inductive-deductive approach on students' mathematical creative thinking ability and self-efficacy. Journal of Innovative Mathematics Learning, 3(4), 215-226.

Martinez, P., Barkokebas, B., Hamzeh, F., Al-Hussein, M., \& Ahmad, R. (2021). A vision-based approach for automatic progress tracking of floor paneling in offsite construction facilities. Automation in Construction, 125. https://doi.org/10.1016/j.autcon.2021.103620

Mollasalehi, S., Rathnayake, A., Aboumoemen, A. A., Underwood, J., Fleming, A., Kulatunga, U., \& Coates, P. (2017). How BIM-lean integration enhances the information management process in the construction design. Proceedings Article published in 25th Annual Conference of the International Group for Lean Construction, 531-538. https://doi.org/10.24928/2017/0130 
Momeni, A., Pincus, M., \& Libien, J. (2018). Cross tabulation and categorical data analysis. An introduction to statistical methods in pathology, 93-120. Cham: Springer.

Ogwueleka, A. C., \& Ikediashi, D. I. (2017). The Future of BIM Technologies in Africa: Prospects and Challenges. In Integrated Building Information Modeling, Wu, P., Li, H., Wang, X. (Eds), 307-314. https://doi.org/10.2174/9781681084572117010016

Olawumi, T. O., \& Chan, D. W. (2018). Identifying and prioritizing the benefits of integrating BIM and sustainability practices in construction projects: A Delphi survey of international experts. Sustainable Cities and Society, 40, 16-27.

Oldfield, J., Bergs, R., van Oosterom, P., Krijnen, T., \& Galano, M. (2018). 3D cadastral lifecycle: An information delivery manual ISO 29481 for 3D data extraction from the building permit application process. In Proceedings of the 7th International FIG Workshop on the Land Administration Domain Model, Zagreb, Croatia, 2018, 12-13.

Oldfield, J., van Oosterom, P., Beetz, J., \& Krijnen, T. (2017). Working with open BIM standards to source legal spaces for a 3D cadastre. ISPRS International Journal of Geo-Information, 6(11), 351. https://doi.org/10.3390/ijgi6110351

Pełczyński, J., Brodniewicz, P., Al Sabouni-Zawadzka, A., \& Gilewski, W. (2021). Design and modeling of glulam beams with holes. IOP Conference Series: Materials Science and Engineering, 1015(1). https://doi.org/10.1088/1757-899x/1015/1/012026

Petrova, E., Romanska, I., Stamenov, M., Svidt, K., \& Jensen, R. L. (2017). Development of an information delivery manual for early-stage BIM-based energy performance assessment and code compliance as a part of DGNB pre-certification. In Proceedings of the 15th International Conference of the International Building Performance Simulation Association.

Pruskova, K., \& Kaiser, J. (2019). Implementation of BIM Technology into the Design Process Using the Scheme of BIM Execution Plan. IOP Conference Series: Materials Science and Engineering, 471. https://doi.org/10.1088/1757-899x/471/2/022019

Ranganathan, P., Pramesh, C. S., \& Aggarwal, R. (2017). Common pitfalls in statistical analysis: Measures of agreement. Perspectives in Clinical Research, 8(4), 187. https://doi.org/10.4103/picr.picr_123_17

Ren, C., Guo, N., \& Chen, B. (2019). Application of 3D design technology based on BIM in substation design. IOP Conference Series: Earth and Environmental Science, 332. https://doi.org/10.1088/1755$1315 / 332 / 4 / 042017$

Rezaei, F., Bulle, C., \& Lesage, P. (2019). Integrating building information modeling and life cycle assessment in the early and detailed building design stages. Building and Environment, 153, 158-167.

Ringle, C. M., Wende, S., \& Becker, J. M. (2015). Smart-PLS 3.2.7. Smart-PLS GmbH.

Röck, M., Hollberg, A., Habert, G., \& Passer, A. (2018a). LCA and BIM: Integrated assessment and visualization of building elements' embodied impacts for design guidance in early stages. Procedia CIRP, 69, 218-223. https://doi.org/10.1016/j.procir.2017.11.087

Röck, M., Hollberg, A., Habert, G., \& Passer, A. (2018b). LCA and BIM: Visualization of environmental potentials in building construction at early design stages. Building and Environment, 140, 153-161. https://doi.org/10.1016/j.buildenv.2018.05.006

Sakin, M., \& Kiroglu, Y. C. (2017). 3D Printing of buildings: Construction of the sustainable houses of the future by BIM. Energy Procedia, 134, 702-711. https://doi.org/10.1016/j.egypro.2017.09.562

Sampaio, A. Z. (2017). BIM as a computer-aided design methodology in civil engineering. Journal of Software Engineering and Applications, 10(2), 194-210. https://doi.org/10.4236/jsea.2017.102012

Santos-Olmo, A., Sánchez, L., Rosado, D., Fernández-Medina, E., \& Piattini, M. (2016). Applying the actionresearch method to develop a methodology to reduce the installation and maintenance times of information security management systems. Future Internet, 8(3), 36. https://doi.org/10.3390/fi8030036

Sha'ar, K. Z., Assaf, S. A., Bambang, T., Babsail, M., \& El Fattah, A. M. A. (2017). Design-construction interface problems in large building construction projects. International Journal of Construction Management, 17(3), 238-250. https://doi.org/10.1080/15623599.2016.1187248

Son, S., Kim, J., \& Ahn, J. (2017). Design structure matrix modeling of a supply chain management system using biperspective group decision. IEEE Transactions on Engineering Management, 64(2), $220-233$. https://doi.org/10.1109/tem.2017.2657652

Son, S., Kim, J., Lee, J., \& Ahn, J. (2019). Improving supply chain management process using design structure matrix based cross-functional analysis. Systems Engineering, 22(4), 313-329. https://doi.org/10.1002/sys.21484

Suryanto, T. L. M., Setyohadi, D. B. S., \& Faroqi, A. (2016). Analysis of the effect of information system quality to intention to reuse of employee management information system (simpeg) based on information systems success model. MATEC Web of Conferences, 58, 03001. https://doi.org/10.1051/matecconf/20165803001 
Sutrisna, M., \& Goulding, J. (2019). Managing information flow and design processes to reduce design risks in offsite construction projects. Engineering, Construction and Architectural Management, 26(2), $267-284$. https://doi.org/10.1108/ecam-11-2017-0250

Sutrisna, M., Ramanayaka, C. D. D., \& Goulding, J. S. (2018). Developing work breakdown structure matrix for managing offsite construction projects. Architectural Engineering and Design Management, 14(5), 381397. https://doi.org/10.1080/17452007.2018.1477728

Taber, K. S. (2018). The use of Cronbach's alpha when developing and reporting research instruments in science education. Research in Science Education, 48(6), 1273-1296. https://doi.org/10.1007/s11165-016-9602-2

Taherdoost, H. (2016). Validity and reliability of the research instrument, how to test the validation of a questionnaire/survey in a research. SSRN Electronic Journal. https://doi.org/10.2139/ssrn.3205040

Tauriainen, M., Marttinen, P., Dave, B., \& Koskela, L. (2016). The Effects of BIM and Lean Construction on Design Management Practices. Procedia Engineering, 164, 567-574. https://doi.org/10.1016/j.proeng.2016.11.659

Troiani, E., Mahamadu, A-M., Manu, P., Kissi, E., Aigbavboa, C., \& Oti, A. (2020). Macro-maturity factors and their influence on micro-level BIM implementation within design firms in Italy. Architectural Engineering and Design Management, 16(3), 209-226. https://doi.org/10.1080/17452007.2020.1738994

Vardanyan, E. (2019). Experience and perspective of using BIM technologies in Armenia. BIM in Construction \& Architecture, 18-23. https://doi.org/10.23968/bimac.2019.003

Villena, F., García-Segura, T., \& Pellicer, E. (2020). Drivers of innovation using BIM in architecture, engineering, and construction firms. Construction Research Congress 2020: Project Management and Controls, Materials, and Contracts. https://doi.org/10.1061/9780784482889.023

von Heyl, J., \& Demir, S-T. (2019). Digitizing lean construction with building information modeling. 27th Annual Conference of the International Group for Lean Construction (IGLC) - Dublin, Ireland, 843-852. https://doi.org/10.24928/2019/0122

Yap, J. B. H., \& Skitmore, M. (2018). Investigating design changes in Malaysian building projects. Architectural Engineering and Design Management, 14(3), 218-238. https://doi.org/10.1080/17452007.2017.1384714

Yassin, A. A., Hamzeh, F., \& Al Sakka, F. (2020). Agent based modeling to optimize workflow of robotic steel and concrete 3D printers. Automation in Construction, 110, 103040. https://doi.org/10.1016/j.autcon.2019.103040

Yousefikhah, S. (2017). Sociology of innovation: Social construction of technology perspective. AD-minister, 30, 31-43. https://doi.org/10.17230/ad-minister.30.2 